DOI: $10.33764 / 2687-041 X-2021-1-254-256$

\title{
СПЕЦИФИКА ОЦЕНКИ ТАУНХАУСА
}

\section{Виктория Анатольевна Дементьева}

Сибирский государственный университет геосистем и технологий, 630108, Россия, г. Новосибирск, ул. Плахотного, 10, обучающийся, тел. (383)361-01-09, e-mail: d-v-a@bk.ru

Оценка таунхауса - сложный процесс, существующий для определения максимально точной цены общего количества квадратных метров данного имущества.

Ключевые слова: оценка, таунхаус, цена, оценщик

\section{TOWNHOUSE ASSESSMENT SPECIFICATIONS}

\section{Victoria A. Dementyeva}

Siberian State University of Geosystems and Technologies, 10, Plakhotnogo St., Novosibirsk, 630108, Russia, Student, phone: (383)361-01-09, e-mail: d-v-a@bk.ru

Townhouse appraisal is a complex process that exists to determine the most accurate price for the total square meters of a given property.

Keywords: appraisal, townhouse, price, appraiser

Таунхаус - жилое помещение на земельном участке, который в большинстве случаев находится за городом. Данный объект сочетает в себе коммуникации, благоустройство квартиры и площадь.

По законодательству РФ при совершении гражданско-правовых сделок недвижимое имущество подлежит обязательному оценочному процессу. Благодаря этому стороны не будут подвержены обману [1]. На рис. 1 приведены основные случаи, при которых нужно проводить данную процедуру.

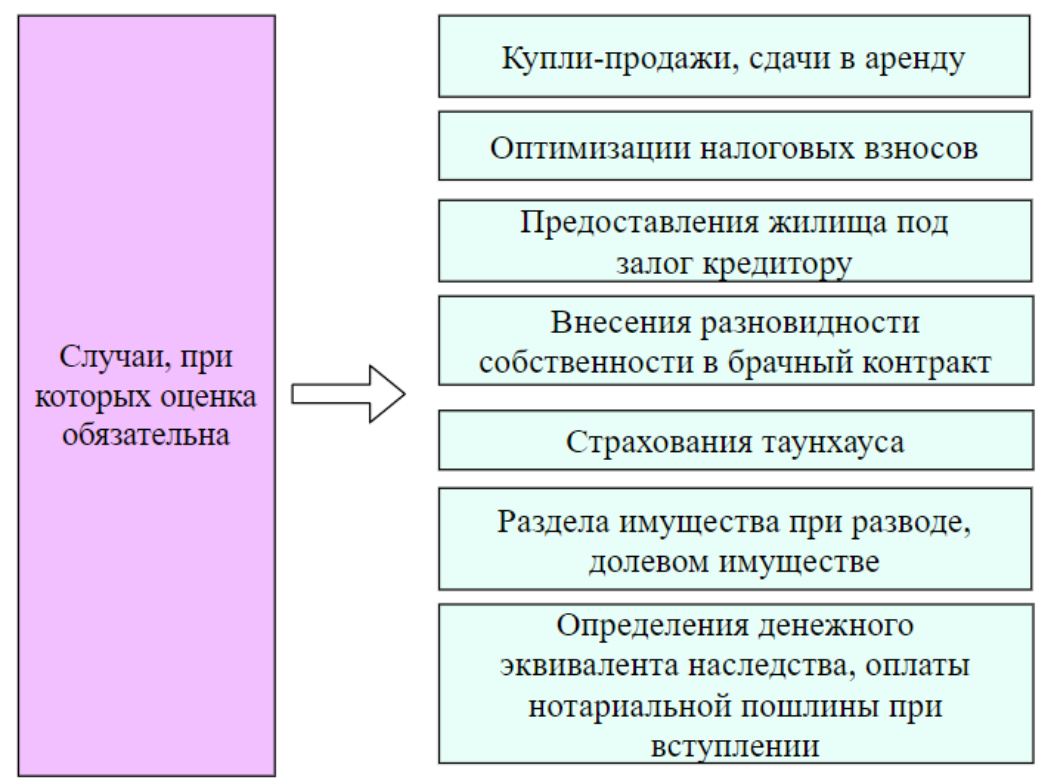

Рис. 1 Случаи, при которых оценка таунхауса обязательна 
В случае если необходимо взыскать задолженность с правообладателя по кредиту, алиментам или незаконному владению, государственные службы заказывают оценку имущества. Также при стихийных бедствиях или других чрезвычайных ситуациях проводят процедуру, чтобы выявить сумму ущерба, которая нужна для страховых выплат и ремонта [2].

Оценку проводят специализированные организации или квалифицированные специалисты. Специалист обязан иметь высшее экономическое образование, быть членом СРО, быть застрахован от ошибки в результатах работы и иметь срок специализации по оценке не менее 1,5-3 лет.

Для начала оценки правообладатель должен обратиться с заявлением в оценочную службу, далее оценщик изучает информацию в заявлении и составляет договор, в котором ставят печать и подписи двух сторон. Договор оформляется в двух экземплярах, один из которых остается в организации, а другой у правообладателя. По завершении оценки заинтересованное лицо оплачивает процедуру. Для точной и адекватной оценки заявитель должен предоставить выписку из ЕГРН, или некоторые документы, касающиеся имущества. Данные документы представлены на рис. 2.

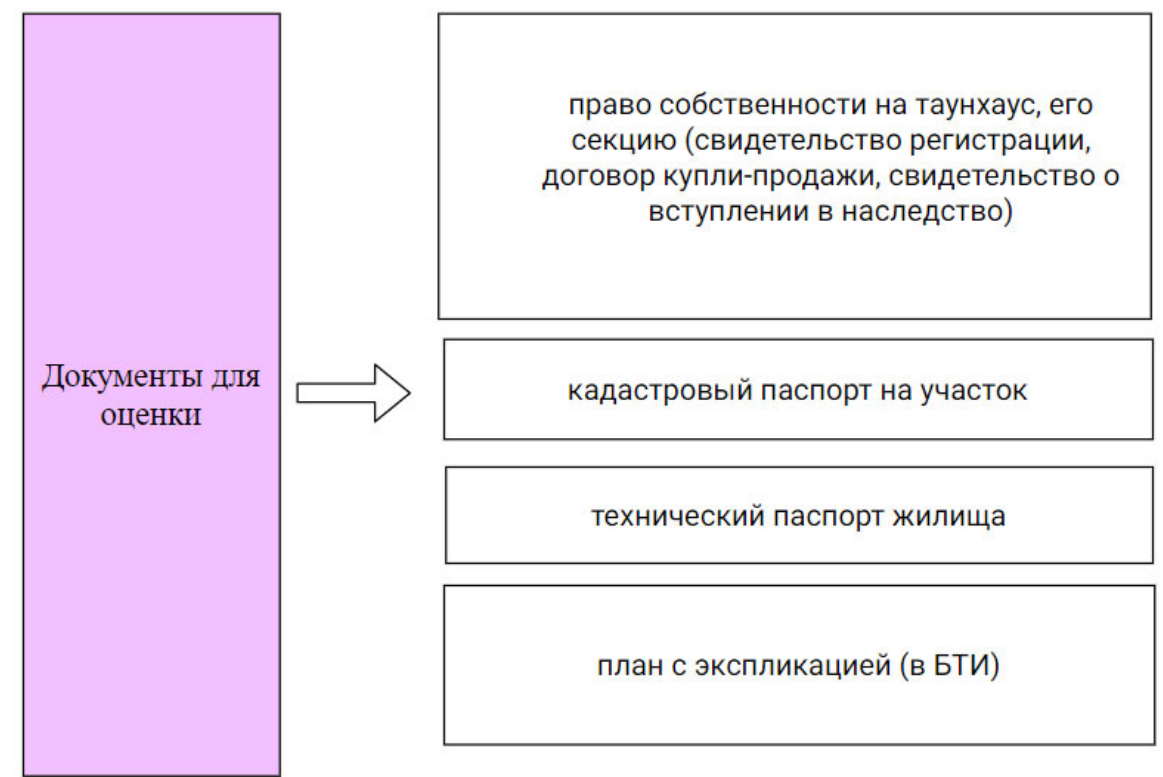

Рис. 2. Документы для оценки

Обязательными документами является паспорт и ИНН заказчика.

При оценке таунхауса стоит обратить особое внимание на указанную информацию в документах. Если данный земельный участок, на котором находится дом, принадлежит к землям населенных пунктов и относится под малоэтажное здание, то это таунхаус. В случае предназначения под индивидуальную застройку, - это загородный дом.

Проведение оценки таунхауса состоит из 6 этапов:

1. проверка и изучение документации;

2. осмотр, детальное изучение объекта, инфраструктуры территории; 
3. выбор метода расчета: доходный, сравнительный или убыточный;

4. расчеты: схемы, расчетные таблицы, снимки;

5. определение рыночной стоимости объекта;

6. фиксация результатов, оформление отчета;

Для выявления цены объекта требуется сравнить как минимум три схожих по характеристикам жилища.

После всей работы оценщик, проводивший работу, оформляет отчет. В отчете должны быть указаны: начало процедуры, регистрационный номер, цели и наименование процедуры, информация об обеих сторонах, перечень документов, итог осмотра имущества, метод проведения работ, итог работ и стоимость объекта. На последней странице оценщик ставит дату окончания процесса, подпись и печать. Также к отчету прикладывают копии снимков, затем нумеруют, прошивают и отдают заказчику. Данный отчет действителен в течение полугода со дня окончания процедуры [3].

\section{БИБЛИОГРАФИЧЕСКИЙ СПИСОК}

1. Боброва Н.П. Некоторые аспекты теории и практики оценки земли: Учебнометодическое пособие. -М. 2004.- 112c.

2. Наназашвили И.Х., Литовченко В.А. Кадастр и оценка земельной собственности: Учебное пособие. М., 2007. - 88 с.

3. Петров В.И. Оценка стоимости земельных участков. Учебное пособие. - 2-е изд., переработанное и доп. М.: 2008. - 224 с.

(C) В. А. Дементьева, 2021 